\title{
エジプト古王国時代における死者祭祀の発展と衰退 The Development and Decline of Private Mortuary Cults in Old Kingdom Egypt
}

\author{
白 井 弥 生 \\ SHIRAI Yayoi
}

\begin{abstract}
The Old Kingdom (ca. 2687-2191BC: 3-6 Dynasties) saw the emergence of large-scale private mortuary cults for the first time in Egypt. This can be observed in the textual attestations of private funerary domains and in the legal documentation pertaining to the administration of mortuary cults. It is however unknown for how long these cults continued to be perpetuated after the death of the tomb owner, nor are the processes of maintenance and abandonment of private mortuary cults during the Old Kingdom well understood. This paper will explore these issues, concentrating primarily on the evidence for architectural modifications to existing cult spaces, the material remains of ritual practice and the archaeological contexts in which such ritual objects have been found. The results of a study of these categories of evidence from five private mortuary cults in the Memphite area are presented in this paper. It is contested that in all cases, the cult continued to be practiced for at least ca. 50-100 years after the death of the beneficiary of the cult. In some cases, the scale of the cult was expanded, possibly due to the integration of additional mortuary cults belonging to individuals buried nearby into a collective cult. Abandonment of the ritual activity is shown not merely to have possibly been a result of the passing of time, but also to have been closely linked to the possible decline of the royal cemeteries at the end of the Old Kingdom.
\end{abstract}

I. はじめに

遺族および関係者が供物奉納などの儀式を通じて故人を祀る「死者祭祀」は，古代世 界で広く営まれた行為の一つであり，古代エジプトでは紀元前3050年頃の王朝成立以降， 王とそれ以外の個人の領域で行われるようになった。個人の死者祭祀については, 古王 国時代（紀元前2687-2191年頃：第 3-6王朝）(図表 1 ) をほぼ境目として, 祭祀に必要な (3)

物資を供給する葬祭領地が設立されるとともに，祭祀に関連する契約文書が出現するこ とから，制度化が進んだことが明らかである。しかしその一方で，こうした制度に基づ

* ベルリン自由大学エジプト学科博士課程

Ph. D. Student, Department of Egyptology, Free University Berlin 
く祭祀が墓主の死後, 実際にどの程度営まれたかという点は明らかでなく, 十分に議論 されてこなかった。墓地で営まれていた祭祀に目を向け，その実態を明らかにすること は, 制度研究が進む古王国時代の死者祭祀を別の側面から捉え直す上で有意義である。 そこで本稿は, 当時の都メンフィスの王墓地で営まれた王族・役人層の祭祀を事例とし て, 墓内碑文, 年代資料としての土器とその出土層位, 墓の改築・増築・破壊行為に関 する建築学的資料を中心に検討しながら, 死者祭祀が営まれた期間, 祭祀が後世に受け 継がれる過程, 祭祀が衰退に向かう過程の 3 点から考察してみたい。

\section{II. 先行研究と資料}

古王国時代の死者祭祀が墓主の死後，早い時期に途絶えたのではないかと考えたのは, カプロニーP. Kaplony である。彼は祭祀執行の役割を担う神官職が, 墓主の子供あるい は葬祭神官など複数の人物に継承される習慣に着目し，この制度では数世代のうちに一 故人に仕える神官の数が増大し，故人が自らの祭祀のために用意した土地をはじめとす る財産が細分されてしまうことを指摘した。彼は財産分散例として, 葬祭神官職, 地域 神ハトホルの神官職, 自身の祭祀の葬祭神官職の 3 つを, 妻と 12 人の子供たちに遺贈し たテへネのニアンクカイイを挙げている。アラム S. Allamもまた, 上記の例をはじめとす る古王国時代の碑文の検討をふまえて, 古王国時代の祭祀の本質は祭祀実行に伴う財産, すなわち墓主の遺産の相続にあったのではないかとし, カプロニーと同様, 古王国時代 の死者祭祀が後世に受け継がれることなく途絶えたのではないかとの考えを示した。こ うした考えは，古王国時代の死者祭祀の意義が祭祀そのものになく，祭祀を通じて引き 継がれる財産にあり，それゆえ祭祀は財産相続後，あるいは財産相続が繰り返されてい く過程で早いうちに衰退したことを言い表している。しかし古王国時代の祭祀が実際に 墓主の死後間もなくして途絶えたかは，別の資料から検証されることなく現在にいたつ ており, 祭祀が途絶えた要因についても上記の資料の性格上, 穿った見方をすれば経済 的側面からしか説明されていないとも取れる。したがって本稿では，どれほどの期間に わたって祭祀は実際に営まれたのかという点を主要な検討課題として取り上げる。

この点を検証できる文字資料はそしく，上記の祭祀取り決めに関する文書も，そこに 記された祭祀が実際にどの程度営まれたのかまでは伝えていない。一方，考古資料や発 掘時の考古学的状況は，文字資料の欠落部分を埋め，時として文字資料以上に雄弁に物 語ることがある。そこで本稿では，墓に付属する祭祀施設の改築，増築，破壞といった 建築上の変化を観察し, 祭祀活動の変化を跡付けるとともに, 祭祀の年代幅を知る上で 有効な出土土器にも着目してみたい。推定される土器の年代は，おおよそ王朝単位とな

ることが多いが, 土器が出土した墓の年代が別の資料から明らかな場合, 王の治世単位 
で推定しうるため, 本稿では以上の手順を踏んで年代が推定されている土器を積極的に 活用する。なお，本稿が準拠する古王国時代の編年は図表 1 に掲載した。

\section{III. 検 討 事 例}

以下ではメンフィス地域の墓地で営まれた 5 つの古王国時代の死者祭祀を検討事例と して取り上げる。特に祭祀期間と，祭祀が行われて衰退するまでの祭祀施設の状況につ いて重点的に検討する。

\section{1. 王女ケケレトネブティ}

ケケレトネブティは, 第 5 王朝 8 代ジェドカラー王の娘であり, 死後, アブシール墓 (12)

地の一画に埋葬された。その墓は1976年に当時のチェコ・スロヴァキア隊によって，隣接 する王子や王女など王族をはじめ，王宮の書記官など生前に王女に近い立場にあった役 (13)

人らの墓とともに発見された（四表 2 )。マスタバ形式からなる王女の墓はジェドカラー

王の在位中に築造されたと考えられており，祭祊は墓の入口部分に位置する小中庭と， その東部の大中庭で行われていたことが確認されている(図表 2 )。小中庭は屋外空間か (16)

らなり，床面近くの堆積層からは祭祀に伴う供物とみられる炭化物，灰，動物骨片，そ

して第 5 王朝後半期から第 6 王朝前半期に年代付けられる土器片が出土した。報告者で あるべルナー M. Verner は土器片の示す年代に基づいて, 王女の祭祀が第 5 王朝後半期

（父王であるジェドカラー王治世以降）から第 6 王朝前半期にかけて小中庭で棠まれた と考えた。

もう 1 箇所の祭祀場所である大中庭（図表 2 ）は，付属施設を含めて幅 $11.4 \mathrm{~m}$ ，奥行 き $7.5 \mathrm{~m}$ ほどの広い屋外空間からなる。大中庭のほぼ中央には 5 つの丸形供物台と I の

字状からなる 1 つの供物台が置かれ，周囲には倉庫と儀式用の給水施設らしき施設が備 (19)

えられていた。小中庭の両脇に位置する倉庫が大中庭が造られる以前のものであること が層位学的に確かめられているため, 大中庭は小中庭よりも年代的に新しいと考えられ る。さらに大中庭の床面が10層にわたって塗り直され, 内部壁面も繰り返し補修されて いることから, この場で行われた祭祀がある時期, 盛行していたことが推察できる。出 土遺物は炭化物, 灰, 動物骨片など, 小中庭で出土した遺物と似た構成となっている。

この大中庭でいつまで祭祀が営まれていたかは,「すでに第 6 王朝初期にケケレトネブ ティのマスタバ前のすべての構造物の機能が徐々に失われつつあつた。この衰退は王女 の祭祀の衰退を示しているにほかならない」とベルナーが述べているように，第 6 王朝 初期までと考えられている。

ベルナーは, 同時代の墓から構成される同墓地（図表 2 ）において, ケケレトネブテ イ王女が一種の「庇護者」になったのではないかと述べているが，この用語は古王国時 
代の墓内碑文にみられる $j m ;$ h h w h $h r j t y n b$ というフレーズに含まれる単語 $j t y$ を指すも のと思われる。この場合，jtyには「ある人物の死者祭祀を庇護する者」という意味合い があったと考えられる。同様の碑文はケケレトネブティ王女の墓がある墓地内部から見 つかっていないが, 王女と親類・主従関係にあった人々が王女の墓の周りに埋葬されて いる事実のほかに，大中庭に設置された 6 つの供物台の存在は，王女を含めた複数の人 物の祭祀がそこで執り行われたこと，なおかつ王女が上記の意味合いでの庇護者として， 同祭祀における中心的人物であったことを想起させるものである。

王女による庇護とは, 具体的には大中庭で執り行われる王女の祭祀で捧げられた供物 が，関係者がまだ存命中であった場合は彼らの生活の糧として，そして関係者が亡くな り周囲に埋葬されてからは, 彼らの祭祀の供物として分け与えられることを意味したの であろう。このような供物を分け与える行為は古代エジプトで $w d b-r d$ とて知られ, 古 王国時代ではとりわけ主従関係にある人々の間で営まれていた。大中庭でこの行為が実 際に行われたという確証はないものの, その場に置かれた複数の供物台の存在と, 王女 と周囲に埋葬された人々の生前の関わりからみて, この $w d b-r d$ が大中庭で行われたと いう可能性は十分に考えられる。

\section{2. 王女ウェネシェト}

ウェネシェトは, ケケレトネブティと同じく王の娘の称号を持ち, 死後, ギザ墓地に 埋葬された (G4840)。墓の造営年代は第 4 王朝中期あるいは末期と考えられている。報 告者ユンカー H. Junker は, 墓の中心部の構造がメンカウラー王治世に特徴的な石材で 築造されていることから，同王が王女の父であると推定している。これが正しいとすれ ば，王女が亡くなった時期は同王の治世以降となり，さらに王女の墓の東面北側に置か

れた偽屝（図表３）に王女が成人した子供たちを伴って描写されていることから, 後年 の第 5 王朝初期頃と位置づけることができる。

祭祀施設はユンカーによって復原が試みられており(図表 3 ), それによると第 4 王朝 末期，まず墓の南東部に石造の礼洋室が無銘の偽屝とともに設置され，王女ウェネシェ トの名前をはじめとする銘文が刻まれた偽扉が墓の北東部に設置された。第 5 王朝時代 になると, 王女の墓の中央やや北寄りの場所に, もうひとつの墓（S984）を含む大型祭 祀施設が日乾煉瓦で造営された。S984の被葬者は明らかではなく, ユンカーは王女の子 供の一人と推定しているが, 王女本人とする説もある。

祭祀施設の入口は隣接する 2 基の墓 (G4940, G4950) の間に造られ, 施設内部は複数の 部屋と通路で細かく仕切られていた。復原図によると, この施設は S984の祭祀場だけで なく, 王女の祭祀を行う礼拝室, および墓北側の偽扉が置かれた空間に通じるように設 計されている。したがって, 施設の目的は王女の祭祀の執行, あるいは S984の被葬者が 
王女とは別人である場合，王女とその人物の祭祀の執行にあったと考えることができる。

後代，祭祀施設は無数のシャフト墓が内部に造られたことにより損壞を受け，通路も

封鎖され，墓北東部の王女の偽扉が置かれた空間も完全に塞がれた。この状況からみ て王女の祭祀は，これらシャフト墓が施設内部に造られた頃すでに途絶えていたと考え られる。この破壊行為が行われた時期について, ユンカーは「後代」としか述べておら ず, 関連資料を再検討したヤノシ P. Jánosi もまた「古王国時代の後の時代」と曖昧な表 現に留めている。

王女の祭祀が途絶えた時期を知るための手がかりとなるのは，祭祀施設の入口部分に 建造された第 6 王朝ぺピ 1 世期のプタハイウフニの墓である(図表 3 破線部)。この墓は 王女の祭祀施設の入口部分の大半を壊して建造されているため，一見すると王女の祭祀 が当時すでに行われていなかったことを示す証拠ととれるが，同墓の位置をよく観察す ると, 王女の施設へと続く大口部分の空間を約 $2 \mathrm{~m}$ 残して建てられていることに気付く。 このように既存の祭祀施設に配慮して新しい墓を建造する行為はギザ墓地でしばしば観 察され，その背後にある施設で当時まだ祭祀が営まれていたことを示唆するものとして 理解できる。この考えが正しければ，王女の祭祀はプタハイウフニの墓が建造されたぺ ピ1世期に，たとえ建物の一部の損壊を許すほどに衰退していたとしても，なおも行わ れていたと考えられる。

\section{3. 幸相メルエフネブエフ}

メルエフネブエフは第 6 王朝初代テティ王の治世以降に, 同王のピラミッドにおける 神官職など複数の役職を経て晚年に宰相となったのち，同王朝 3 代ぺピ 1 世の時代に亡 くなった人物である。彼の墓はサッカーラ墓地のジェセル王のピラミッド複合体周壁の 西方に位置し，1997年，ポーランド・エジプト共同調査隊によって発見された。

この人物の祭祀は, 岩窟形式からなる西側礼帱室と, マスタバ形式の上部構造東側に 設けられた屋外の東側礼洋室の 2 箇所で確認されている (図表 4 )。西側礼洋室は 2 つの 偽屝と供物台を内部に備え，壁面は彩色レリーフで飾られていた。室内からは鉢や器台， ミニチュア土器, ビール喆など, 祭祀活動の存在を示す土器が多数出土している。古王 国時代よりも後の時代の遺物が礼捀室から 1 点も見つかっていない点から，そこで第 6 王朝時代を超えて祭跑が営まれたとは考えにくい。さらに出土ビール壶の年代を詳細に 検討したジョウスカ T. I. Rzeuska により, 西側礼择室での祭祀が第 6 王朝 4 代メルエ ンラー王の治世までは営まれていたと考えられている。これは調査出土のビール壹が形 態, 製作技法, 出土状況, 類例から夕イプ 1 (第 6 王朝前半期), タイプ 2 (同後半期), タイプ 3 (同中期 : ペピ 1 世治世末〜メルエンラー王治世) に分類可能で, 西側礼拝室 ではこのうちタイプ3のビール劽が認められたためである。 
東側礼拝室（図表 4) は，西側礼拝室が墓の上部に積まれていた日乾煉瓦壁体の崩壊 によって塞がれた後, 代わりに設置された祭祀場と考えられている。同礼拝室は本来, 墓の上部構造である泥煉瓦壁体を一部掘り込んだ場所に, 墓主の銘を刻んだ偽扉と供物 台が置かれただけの簡素な屋外施設であった。しかし，3 期にわたる祭祀活動面が祭祀 場の床面から認められているほが, 礼帱室を新たに囲う保護壁（図表 4 ）が同室の北側 に造られ, 施設全体が増築されていることから, 祭祀は継続・発展していたものと推察 される。供物台の周囲からは灰, 動物骨, 土器片などの祭祀関連遺物が多数出土してい るほか，床面には供物を焼いて奉納する「はん祭」が行われたことを示す焼成面も検出 されている。 3 期にわたる祭祀活動面のうち最上面は, 出土した土器の年代から第 6 王 朝最末期のものとされ，これにより東側礼洋室における祭祀は当該期まで営まれた後に 途絶えたものと考えられる。

\section{4.「第13号礼拝室」被葬者}

前述のポーランド・エジプト共同調查隊による発掘は，ジェセル王の複合体の周囲を めぐっていたとみられる空壕の存在と, その内部の岩壁を利用して造られた古王国時代 後半期の岩窟墓群の存在を明らかにした。

そのうちの一基, 被葬者不明の墓である通称「第13号礼拝室」(図表 5 ) は, 祭祀場で ある礼帱室と, その床面に掘られた 8 つのシャフトからなる集合墓である。造営年代は 第 6 王朝のぺピ 1 世からメルエンラー王治世以降とすることができるが，それは第 13 号 礼洋室が建築学的にみて隣接する岩窟墓「第14号礼择室」よりも明らかに後代に年代付 (58) けられ, かつ第14号礼洋室が墓内碑文の内容により, ペピ 1 世からメルエンラー王治世 下の人物の墓とみられるためである。加えて, 両墓から出土した一部の土器が, 同じ製 作者の手による可能性があるほど形状と製作技法の点で非常に似通っている点から, 両 墓は年代的に大きく離れていないとみられる。そのため被葬者不明の資料ながら, 本稿 では積極的に同墓出土資料を検討に加えていくことにする。

この第13号礼捀室で祭祀がいつまで営まれたかについては, 出土した祭祀関連土器を 検討したジョウスカにより，ぺピ 1 世あるいはメルエンラー王治世から第 6 王朝末期ま でとされている。その根拠となった礼洋室出土の土器は, 古王国第 6 王朝後半期および 末期に特徴的な土器 (図表 $6 \mathrm{a}-\mathrm{c}$ ) のみで構成されている。

\section{5.「第 2 通廊」被葬者}

上記の空壕の内壁に穿たれたもう一基の岩窟墓「第 2 通廊」(図表 7 ) においても, 出 土土器に基づいて同墓で営まれた祭祀の時期について検討することができる。この墓は

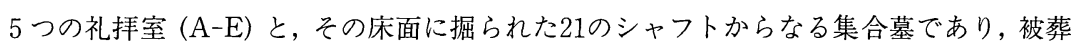
者は明らかでない。しかし各礼帱室からは，はん祭において燃やされた供物が炭化して 
こびりついた浅血（図表 8a）や，供物血を据える器台として用いられた土器の一部（図 表 8b) などの祭祀関連土器が出土しているほか，同通廊から出土したすべての土器が,

類例にペピ 2 世期のビール壼（図表 8c) が認められるなど実質的に第 6 王朝後半期以降 (66)

の土器に由来することも明らかである。したがって本例も検討事例に加えたい。これら 出土土器には遺体埋葬時に副葬品としてシャフトに納められた土器も含まれることから, この墓における埋葬開始の年代も第 6 王朝後半期以降と考えられる。最も新しい年代に 推定されている祭祀関連土器は，第 6 王朝末期あるいは第 1 中間期初期に推定されてい る器台 (図表 8b) である。以上のことから, 第 2 通廊はぺピ 2 世期以降に埋葬利用が始 まり, その後礼拝室で営まれた祭祀は遅くとも第 1 中間期の初期まで継続されたとみる ことができるだろう。

\section{IV. 考 察}

以上の検討事例に基づいて，1．死者祭祀が営まれた期間， 2 . 祭祀が後世に受け継 がれる過程，3．祭祀が衰退に向かう過程の 3 点について考察する。

\section{1. 死者祭祀が営まれた期間}

祭祀関連の遺物および祭祀施設の状況からみて，検討事例で取り上げたいずれの祭祀 も墓主の死後, 実際に営まれたことはほぼ間違いない。各祭祀が営まれた期間について の考察は，歴代王の統治年数も含めて古王国時代の編年が確定していないため，概算が できる程度に過ぎないが，これまでこうした試算が行われなかったことをふまえれば, 一定の意義があるものと考える。なお本稿では, 祭祀の開始時期を墓主の死後, 厳密に

は埋葬儀式後としている。ただし, 墓主の亡くなった時期が必ずしも明確でない祭祀も あり，その場合，墓あるいは祭祀施設の建造期が墓主が亡くなった時期と大差ないもの とみなし，その時期をもって祭祀の開始時期と仮定する。 5 つの祭祀の期間について検 討事例で述べた内容に基づいて試算すると，次のようになる。

王女ケケレトネブティの祭祀は, 父王である第 5 王朝ジェドカラー王の治世後半期以 降に開始され, 第 6 王朝初期には衰退に向かい, 遅くとも第 6 王朝前半期までに途絶え たと考えられる。祭祀期間は少なくともジェドカラー王治世後半期の終りから第 6 王朝 初期までの約50 70年間, 多く見積もった場合, 同王治世後半期から第 6 王朝前半期末ま での約130年間とみられる。

王女ウェネシェトの祭祀は第 5 王朝初期に開始され, 第 6 王朝ペピ 1 世治世を経た後, 第 6 王朝末期に至る間に途絶えたと考えられる。祭祀期間は少なくとも第 5 王朝初期か らメルエンラー王治世初期までの約190 200年間, 多く見積もった場合, 第 5 王朝初期か ら第 6 王朝末期までの約 320 年間と想定できる。 
宰相メルエフネブエフの祭祀は, 第 6 王朝ぺピ 1 世治世に開始され同王朝の末期に途 絶えたと思われる。祭祀期間は少なくともぺピ 1 世治世の後半期以降から第 6 王朝末期 までの約120 140年間，多く見積もつて同王治世前半期から第 6 王朝末期までの 約140～160年間と想定できる。

第13号礼拝室被葬者の祭祀は, 第 6 王朝ペピ 1 世あるいは次王メルエンラー王の治世 下に開始され，同王朝末期に途絶えたと考えられる。祭祀期間は少なく見積もって，メ ルエンラー治世の末頃からぺピ 2 世治世の中頃までの約 60 ～70年間，多く見積もってぺ ピ 1 世治世初期から第 6 王朝末期までの約150 160年間と想定できる。

第 2 通廊被葬者の祭祀は第 6 王朝ペピ 2 世の治世下に開始され, 第 1 中間期初期まで に途絶えた可能性が高い。祭祀がぺピ 2 世の治世後半以降に開始されたとすると 約50〜60年，同王治世初期に開始されたとすれば約100〜110年にわたって続けられたと 想定できる。

試算された上記の祭形期間は見積もり方次第で大きく変わるため，あくまでも祭祀期 間を知りうる一つの目安として捉えるべきであろう。しかし，試算結果からは少なくと も検討事例で扱った祭祀が開始された後すぐに途絶えたわけではないことが言え，さら に期間が最も短いとみられる王女ケケレトネブティと第 2 通廊被葬者の祭祀も，少なく とも50年間は続けられたとみることができる。王女ウェネシェトの祭祀にいたっては, プタハイウニの墓をめぐる解釈が正しいとすると約190年間, 宰相メルエフネブエフの祭 祀は約120年間と，少なくとも100年以上にわたり営まれ続けていた可能性すら考えられ る。この試算結果は, 祭祀が開始されて早いうちに衰退したとする先述のカプロニーら の考えにそぐわないものと言え，むしろ祭祀は一定期間にわたって継続されていたとみ るほうが妥当である。以下の 2 節では, 祭祀が後世に受け継がれ, 後に衰退に向かう過 程とはどのようなものであったのかを考察する。

\section{2. 祭祀が後世に受け継がれる過程}

事例として扱った祭祀のなかでも，王女ケケレトネブティ，王女ウェネシェト，宰相 メルエフネブエフの 3 例は, 祭祀が営まれていた間の祭祀施設の変遷が追える点で, 祭 祀が後世に受け継がれる過程を知る手がかりとなる。これら 3 例は, 当初の祭祀施設が 時間の経過とともに増築され, 大型化している点で共通しており, 王女ケケレトネブテ イの場合, 小中庭に加えて後年に大中庭という広い空間（図表 2 ）でも祭祀が営まれて いたことが確認されている。しかも祭祀施設の補修が繰り返されたことからみて，その 祭祀はある期間盛行し, 間断なく続いていたと言える。王女ウェネシェトの祭祀施設 (図 表 3 ）もまた，礼拝室内と偽扉の前にあった祭祀場に加え，これらを包含する大型の日 乾煉瓦製の祭祀施設が第 5 王朝時代に入って造られている。幸相メルエフネブエフの場 
合，西側礼拝室の封鎖に伴い，上部構造に接して東側礼洋室（図表 5 ）が新たに造られ た。この場で営まれた祭永が施設の増築を伴いながら後世に受け継がれていったことは， 3 期にわたる祭祀活動面と，礼洋室北側に造られた新たな保護壁の存在から確認できる。 3 例にみる祭祀施設の大型化現象は, すなわちそこで営まれた祭祀の規模拡大を示すも のとして考えられる。

こうした祭祀の規模拡大はどのような背景のもとに行われたのであろうか。祭祀施設 の大型化が確認された 3 例のうち王女ケケレトネブティの場合, 王女の墓の周囲に埋葬 された人々 (図表 2 ) のため, 大中庭で行われた王女の祭祀の供物が分与されていた可 能性については，検討事例で述べた通りである。これは本来の墓主の祭祀が後世に受け 継がれる過程で他者の祭祀と結びつけられ, 一個人の祭祀の域を超え, 集合祭祀として の性格を併せ持つかたちで拡大された可能性が考えられる。

王女ウェネシェトの場合, 祭祀場である礼择室と偽扉の前の空間に加えて, 第 5 王朝 時代には, 日乾煉瓦製の祭祀施設がもう 1 基の墓 S984 とともに造られている（図表 3 )。 前述のように, S984の被葬者は王女本人か, その子供とされているが，王女本人だとす ると, S984には付属する祭祀場が伴うことから, 王女の祭祀場は日乾煉瓦祭祀施設内部 だけで合計 3 箇所となる。このように, 一人の人物が 3 箇所もの祭祀場をひとつの施設 の内部に持つとことは極めて稀であり, むしろ S984には王女の子供あるいは別の人物 が埋葬され，同時に祭祀場が新たに設けられたと考えるほうが自然であろう。だとすれ ば，王女ウェネシェトの祭祀も王女ケケレトネブティの場合と同じく，後年になり他者 の祭祀と祭祀施設を共有する形で結びつけられ，規模が拡大されたとみることができる。

一方, 宰相メルエフネブエフの場合, 東部礼拝室の大型化は確認されているものの (図 表 5 ), 上記 2 例とは異なり, 他者の祭祀が墓主の祭祀と結びつけられた痕跡は認められ ない。

以上のように, 祭祀は後年その規模が拡大される場合があり, その背景として, 王女 ケケレトネブティと王女ウェネシェトの例のように, 墓主の祭祀が他者の祭祀と結びつ けられ，集合祭祀として後世に受け継がれ，発展する場合があったことが考えられる。

\section{3. 祭祀が衰退に向かう過程}

王女ケケレトネブティの場合, 小中庭と大中庭での祭祀が第 6 王朝初期に衰退に向か い，同王朝前期までに完全に途絶えたであろうことは，先に述べた通りである。この祭 祀の衰退を示す具体的な事象としては，祭祀施設（図表 2 ）の封鎖と荒廃が挙げられる。 小中庭の南北に位置する倉庫（図表 2 ）のうち, 北側倉庫の最奥の部屋は日乾煉瓦の壁 により封鎖されている。さらにこの両倉庫と, 小中庭, 大中庭の各所が次第に砂に埋も れていき，そこに祭祀施設の建材である日乾煉瓦が倒壊したとみられる。このような状 
況からみて，王女の祭祀は時とともに次第に衰退したと理解できる。

王女ウェネシェトの場合も, 祭祀施設（図表 3 ）の一部が第 6 王朝時代に入ってプタ 八イウニの墓により破壊されている。これは当時の王女の祭祀がすでに施設の破壊を許 すほどに衰退していたことを示しており，施設破壊を伴う漸次的な衰退の末に，王女の 祭祀は完全に途絶えたと考えられる。

一方，宰相メルエフネブエフの場合 (図表 5 )，西側礼帱室が墓の上部構造であった泥 煉瓦壁体の崩壊によって封鎖されているものの, 祭祀は後に東側礼拝室で第 6 王朝末ま で営まれ続けている。祭祀衰退を示す施設の縮小や破壊, 倒壊といった明瞭な痕跡は, この東側礼洋室では認められておらず, サッカーラ西部墓地に位置する第13号礼洋室と 第 2 通廊においても同様である。この点で宰相メルエフネブエフの祭祀と 2 基の岩窟墓 における祭祀の衰退過程は, 先の 2 例とやや異なる。

サッカーラ西部墓地全体の層位に関する上記のポーランド・エジプト共同調査隊の報 告によれば，ジェセル王のピラミッド西部域に広がるこの墓地では第 6 王朝末期，すな わち古王国時代の終焉を境に人々の活動の痕跡がほとんど見られなくなるといゔ。だと すれば，宰相メルエフネブエフの祭祀は時間の経過に伴って緩やかに衰退し途絶えたと いうょりも, 古王国時代末期におけるサッカーラ西部墓地全体の衰退に伴って祭祀もま た衰退したとの見方が成り立つ。この墓地に位置する第 13 号礼帱室と第 2 通廊における 祭祀についても, 前者が第 6 王朝末期, 後者が第 1 中間期初期までに完全に途絶えた可 能性が高いことから，同様に古王国時代における墓地全体の衰退がこれらの祭祀の存続 に大きく関係していたと考えられる。

古王国時代末期における墓地全体の衰退は, このサッカーラ西部墓地に限ったことで なく, 当時の都メンフィスの他の王墓地でも確認されている。たとえば, ギザ墓地では 多くの墓が第 1 中間期に入り破壞, 略奪を受け, 旧来の祭祀施設には数多くのシャフト 墓が造られたり, 彫像を納めるセルダブが墓へと転用されている。さらに既存の墓の祭 祀施設に続く通路が新しい墓によって封鎖されるなど, 旧来守られてきていた墓地の秩 序が, 第 5 王朝末期頃から次第に失われつつあったことも指摘されている。ギザ墓地は サッカーラ西部墓地と違って第一中間期以降も機能し続けたが，それでも古王国時代末 期から第一中間期初期を境目に, 墓地の様相が大きく変化した点で両墓地は共通してい る。

\section{V. 結 び}

本稿では検討事例に基づき, 死者祭祀が営まれた期間, 祭祀が後世に受け継がれる過 程, 祭祀が衰退に向かう過程の 3 点から考察を行った。その内容をまとめ, 結びとした 
W。

検討事例で取り上げたいずれの死者祭祀も, 墓主の死後, 墓に付属する祭祀施設で一 定期間にわたり実際に営まれたことはほほ間違いない。試算に基づく限り，少なくとも 50 年以上，なかには 100 年以上にわたって営まれ続けた祭祀があったとすることができ る。これは死者祭祀の本質が墓主の財産相続にあり, そのため祭祀は財産相続後早い時 期に途絶えたとした従来の見解に修正を迫るものである。さらに，祭祀は開始後次第に 衰退するとした従来の説とは異なり，検討事例では祭祀施設の規模が拡張される場合が 認められた。その背景の一つとして, 墓主の祭祀が他者の祭祀と結びつき, 集合祭祀と しての性格を帯びながら後世に受け継がれ，発展することがあったとすることができる。 祭祀が衰退に向かう過程は必ずしも一様ではなく, 時間の経過とともに緩やかに衰退に 向かう場合と, 古王国時代末期まで祭祀が存続し, 当時の墓地全体の荒廃との関わりの 中で衰退する場合があったことが確認できる。前者の場合, 祭祀は時の流れとともに次 第に忘れ去られたものとみられるが, 後者の場合, 墓地全体の荒廃が主要因となって祭 祀が衰退に追い込まれた可能性が高い。当時の墓地の衰退と荒廃は，とりもなおさずメ ンフィス地域における墓地の管理の破綻, ひいてはその墓地の管理を司っていた中央政 府の管理能力の低下を示すものとして理解することができるだろう。

注

文献と図版出典の略語表記は W. Helck \& W. Westendorf (eds.). Lexikon der Ägyptologie. Vol. 7. Wiesbaden: Otto Harrasowitz. 1992 に準拠する。

（1）「死者祭祀」という用語は, mortuary cult, funerary cult, cult of the dead, Totenkult, cult funréraire の邦訳である。

( 2 ) J. Taylor, "Death, the Afterlife, and Other Last Things: Egypt-Earlier period," in S. I. Johnston (ed.), Religions of the Ancient World, Cambridge and London: The Belknap Press, 2004, 471.

(3) Jacquet-Gordon, Domaines.

（4）祭祀について取り決めた文書はjimj.t-pr と呼ばれる文書の一種であり，その集成 研究については, H. Goedicke, Die privaten Rechtsinschriften aus dem Alten Reich, Wien: Notring, 1970. を参照。この種の最古の文書は, 第 3 王朝から第 4 王朝にかけて の過渡期に見られるメチェンの文書である（H. Goedicke, “Die Laufbahn des Mtn," MDAIK 21 (1966), 1-71)。

( 5 ) P. Kaplony, "Die wirtschaftliche Bedeutung des Totenkultes im alten Ägypten," Asiatische Studien 18/19 (1965), 290-307.

（6）この人物の称号については，Urk. I, 24-28. を参照。文書が書き記された新旧 2 基 の墓のうち, 旧墓については, Urk. I, 161-163; E. Edel, Hieroglyphische Inschriften des 
Alten Reiches, Opladen: Westdeutscher Verlag, 1981, 53-57 を参照。新墓については, Urk. I, 24-32; Edel, Inschriften, 38-52. を参照。

( 7 ) S. Allam, "Vom Stiftungswesen der alten Ägypten," Das Altertum 20 (1974), $131-146$.

（8）ただし，メンフィス地域の土器の編年研究は，ギザ墓地から出土した資料を対象 にほほ確立しているほかは, マイドゥーム土器, パン型, ビール监という限られた器 種の編年研究が進んでいるに過ぎない。そのため古王国時代の土器の年代は, これら の編年研究に頼るほかに, 各遺跡の発掘報告に類例を求め, さらに土器の出土状況を 考慮して推定する手法が取られる。ギザ出土土器資料の集成研究については, G. A. Reisner, A History of the Giza Necroplis, vol. 2, Cambridge: Harvard University Press, 1955, 60-89 を参照。マイドゥーム土器の研究については, たとえば L. Ob de Beek, "Possibilities and Restrictions for the Use of Maidum-Bowls as Chronological Indicators," Cahiers de la céramique égyptienne 7 (2004), 239-280を参照。パン型の研 究については, H.K. Jacquet-Gordon, “A Tentative Typology of Egyptian Bread Moulds," in D. Arnold (Hrg.), Studien zur altägyptischen Keramik, SDAIK 9, Mainz am Rhein: Verlag Phillip von Zabern, 1981, 11-24 を参照。ビール壸の研究について は, D. Faltings, Die Keramik der Lebensmittelproduktion im Alten Reich: Ikonographie und Archäologie eines Gebrauchsartikels, Studien zur Archäologie und Geschichte Altägyptens 14, Heidelberg: Heidelberger Orientverlag, 1998 を参照。

（9）たとえばマイドゥーム土器の最大径に対する器高の割合から導き出される值の違 いや (Ob de Beek, Maidum-Bowls, 253, fig. 5b), ビール壶の器形上の特徵から

(Faltings, Keramik, 209-222), 土器の王朝区分が試みられている。

（10）たとえば Reisner, Giza，69-89 を参照。

(11) 王女の称号については, M. Verner \& G. Callender, Abusir VI: Djedkare's Family Cemetery, Prague: Czech Institute of Egyptology, 2002, 13-14 を参照。

(12) Ibid., 13-53, 77-84.

（13）同墓地に埋葬された人々の社会的地位については, Verner \& Callender, Abusir VI, 133-140を参照。

(14) Ibid., 105.

(15) Ibid., 77-84.

（16）Ibid., 80-81, fig. F4 (第 4 層).

(17) Ibid., 79.

(18) Ibid., Pls. 19, Ff2-20, Ff3.

(19) Ibid., 83.

(20) Ibid.

（21） Ibid., 82-83, fig. F6 (第 8 層).

(22) Ibid., 84. 
（23）年代の根拠は明示されていないが, 両中庭から出土した土器をはじめとする祭祀 関連遺物に基づいていると思われる。

(24) Ibid.

（25）例えばUrk. I, 82, 14; 188, 1-2.

(26) $W b .1,143$.

（27）jtyを「庇護者」と解釈している先行研究については，例えば Goedicke, H., Die Privaten Rechtsinschriften aus dem Alten Reich, Wien: Notring, 71 を参照。jm;hw hrr （X）の具体的な意味は，「祭祀を通じて（X) と経済的・社会的な結びつきを持つ者」 と理解されている (K. Jansen-Winkeln, “Zur Bedeutung von jm;h,” BSEG 20 (1996), 36)。すなわち，ある個人の墓に記された jm; h 護者の支援のもとで, 死者祭祀が執り行われる者」として解釈できるだろう。

（28）庇護する側とされる側の両者の墓が墓地で隣接する例が，ギザ墓地で認められて いる。ペンメルウの墓（G2197）には，「庇護者」(jty) として隣接する墓の主センネフ エル（G5170）の名前が記されていた。両墓は 2 基の墓を隔てて位置する関係にあった

(B. Grdseloff, "l'inscription de Penmerou," ASAE 42 (1943), 39-63)。

（29）上記のペンメルウの墓とセシェムネフェルの墓の間においても $w d b-r d$ が行わ れていたことがペンメルウの墓内碑文に記されている（Ibid, 39.)。ペンメルウの称号

$(j m j-r) h m w-k j)$ から判断して, 彼はセシェムネフェルの葬祭神官長であった可能性 がある (Ibid.)。このほかの wdb-rd についての議論と事例については, Junker, Gîza III, 4-8 を参照。

（30）墓主の称号と関連議論については, Junker, Gîza I, 251-255; P. Jánosi, Giza in der 4. Dynastie: die Baugeschichte und Belegung einer Nekropole des Alten Reiches, Band. I, UÖA 24, Wien: Verlag der Östereichischen Akademie der Wissenschaften, 2005, $128,201,230$ を参照。

(31) Junker, Gîza I, 249-259.

(32) Ibid., 251; Jánosi, Giza, 230.

(33) Junker, Gîza I, 251.

(34) Ibid., Abb. 63.

(35) Junker, Gîza VII, 17-24, Abb. 4, 6.

（36）この S984 と祭祀施設の年代は，その壁の一部が第 5 王朝前半期の墓 (G4940) に 寄りかかるように造られていることから，第 5 王朝以降と考えられている（Junker, Gîza VII, 24)。

(37) Ibid., 22.

(38) Reisner, Giza, 500.

(39) Junker, Gîza VII, Abb. 4.

(40) Ibid., Taf. VI.

(41) Ibid., 21. 
(42) Jánosi, Giza, 202.

(43) Junker, Gîza VII, 24-26, Abb. 4.

(44) Junker, Gîza III, 123; A. M. Roth, A Cemetery of Palace Attendants, Boston: Museum of Fine Arts, Boston, 1995, 27-32.

(45) K. Myśliwiec, “A new mastaba, a new vizier,” Egyptian Archaeology 13 (1998), 38. 墓主の称号については，K. O. Kuraszkiewicz, “False-door stele of Meref-nebef,” Polish Archaeology in Mediterranean (以下 PAM と略記) 10 (1999), 101-105 を参照。 墓主が亡くなった時期については, K. Myśliwiec et al., Saqqara I: The Tomb of Merefnebef, Warsaw: Zaś Pan \& Neriton, 2004, 247 を参照。

(46) K. Myśliwiec, “West Saqqara: Excavation 1997," PAM 9 (1998), 90-99.

(47) Myśliwiec et al., Saqqara I, 208-209.

(48) K. Mysliwiec, in M. Bárta \& J. Krečí (eds.), Abusir and Saqqara in the Year 2000, Prague: Oriental Institute, 2000, 500.

(49) Myśliwiec et al., Saqqara I, 209.

(50) Myśliwiec et al., Saqqara I, 249.

(51) A. Cwiek, A. "The Stratigraphy of West Saqqara: preliminary remarks, " $P A M$ 11, 133-134, fig. 4 .

(52) Myśliwiec et al., Saqqara I, Pl. 81 b.

(53) Myśliwiec et al., Saqqara I, Pl. $81 \mathrm{~g}$.

(54) K. Myśliwiec, “West Saqqara: Excavation 2001,” PAM 13 (2002), 134.

(55) メルエフネブエフの墓の東側に位置する別の墓 (第 2 葬祭複合体) 出土土器が類例 として挙げられている (Myśliwiec et al., Saqqara I, 209.)

（56）空壕と岩窟墓群の位置関係については, Myśliwiec et al., Saqqara I, Pls. 3, 4 を参 照。

(57) Myśliwiec, "West Saqqara in 2002," PAM 14, 121-125.

(58) T. I. Rzeuska, "The Pottery, 2002," PAM 14, 148.

（59）墓内碑文については，K. O. Kuraszkiewicz, “Saqqara 2002: Inscriptions,” $P A M$ 14 (2003), 137-140を参照。

(60) 第13号礼拝室出土土器 (SQ02-1166) との類似性が挙げられている (Rzeuska, “The Pottery, 2002," PAM 14, 149. 図は Ibid., 147, fig. 4)。

(61) Ibid., 149.

（62）粗いナイルシルトの胎土に赤色のスリップが表面にかけられ, 底部に削り加工が 施された土器からなる。

(63) K. Myśliwiec, "West Saqqara: Excavation 2000," PAM 12 (2001), 116-118, figs 4,5 .

(64) Rzeuska, “The Pottery, 2002," PAM 14, 144-145, fig. 5.

（65）Ibid., 145, fig. 6. 第 6 王朝ぺピ 2 世期のビール壹が類例として挙げられている（G. 
Jéqiuer, Tombeux de particuliers contemprains de Pepi II, Cairo: IFAO, 1929, fig. $30)$ 。

(66) Ibid., 145.

(67) T. I. Rzeuska, "The pottery 2003," PAM 15 (2004), 136.

(68) T. I. Rzeuska, "The pottery," PAM 12 (2001), 145.

（69）祭祀の開始時期については，筆者が別稿で論じている。Y. Shirai, “Ideal and Reality in Old Kingdom Private Funerary Cults," in M. Bárta (ed.), Old Kingdom Art and Archaeology: Proceedings of a Conference, Prague 2004, Prague: Czech Institute of Egyptology (forthcoming).

(70) Myśliwiec et al., Saqqara I, Pl. $81 \mathrm{~g}$.

（71） ギザ墓地のセネジェムイブ一族の複合体（G2370, G2378 他）でも，一族構成員の 墓が中庭を取り囲むようにして造られており，中庭には祭祀が行われたことを示唆す る献水容器が設置されていた。こうした建築学上の特徴とからみて, この中庭でも一 族構成員を対象とした集合祭祀が営まれていたと考えられる。同複合体の年代は, 第 5 王朝ジェドカラー王治世から第 6 王朝時代にかけてであり, ケケレトネブティ王女 の墓が位置するアブシール墓地とほぼ同時期である。同複合体の平面図, 時期につい ては E. Brovarski, The Senedjemib Complex Part I: The Mastabas of Senedjemib Inti (G 2370), Khunumenti ( $G 2374$ ), and Senedjemib Mehi ( $G$ 2378), Boston: Museum of Fine Arts, Boston, 2001 を参照。

(72) Verner \& Callender, Abusir VI, 82.

(73) Ibid., 77-83.

(74) Z. E. Szafrański, "Observation on Stratigraphy," PAM 10 (1999) 95; Myśliwiec, new mastaba, 37.

(75) Junker, Gîza VI, 166, 227.

(76) Roth, Attendants, 37-38. 
第 3 王朝 前2687-2649頃

第 4 王朝 前2649-2513頃

$$
\begin{array}{ll}
\text { スネフェル } & 2649-2609 \\
\text { クフ } & 2609-2584 \\
\text { ジェドェフラー } & 2584-2576 \\
\text { カフラー } & 2576-2551 \\
\text { メンカウラー } & 2551-2523 \\
\text { シェプセスカフ } & 2523-2519 \\
\text { ( } 2 \text { 人の王) } & 2519-2513
\end{array}
$$

第 5 王朝 前2513-2374頃

$$
\begin{array}{ll}
\text { ウセルカフ } & 2513-2506 \\
\text { サフラー } & 2506-2492 \\
\text { ネフェルイルカラー } & 2492-2482 \\
\text { シェプセスカラー } & 2482-2475 \\
\text { ネフェルエフラー } & 2475-2474 \\
\text { ニウセルラー } & 2474-2444 \\
\text { メンカウホル } & 2444-2436 \\
\text { ジェドカラー } & 2436-2404 \\
\text { ウナス } & 2404-2374
\end{array}
$$

第 6 王朝 前2374-2191頃

$$
\begin{array}{ll}
\text { テティ } & 2374-2354 \\
\text { ウセルカラー } & ? \\
\text { ペピ1世 } & 2354-2310 \\
\text { メルエンラー } & 2310-2300 \\
\text { ペピ2世 } & 2300-2206 \\
\text { アンティエムサフ } & 2206 \\
\text { ニトイケルティ } & 2205-2200 \\
\text { ネフェルカ } & 2200-2199 \\
\text { ネフェル } & 2199-2197 \\
\text { アバ } & 2197-2193 \\
- & 2193-2191 \\
- & 2191
\end{array}
$$

( 1 未満)

図表 $1 ：$ 編年表 (D. B. Redford (ed.), The Oxford Encyclopedia of Ancient Egypt, Oxford: Oxford University Press, 2001, 3 vols. 巻末編年表を改变)

* 年代は全て概算である。

*カッコ内は推定統治年数である。

*本文中で取り上げる第 4 王朝から第 6 王朝までの

期間は，歴代王別に示した。 


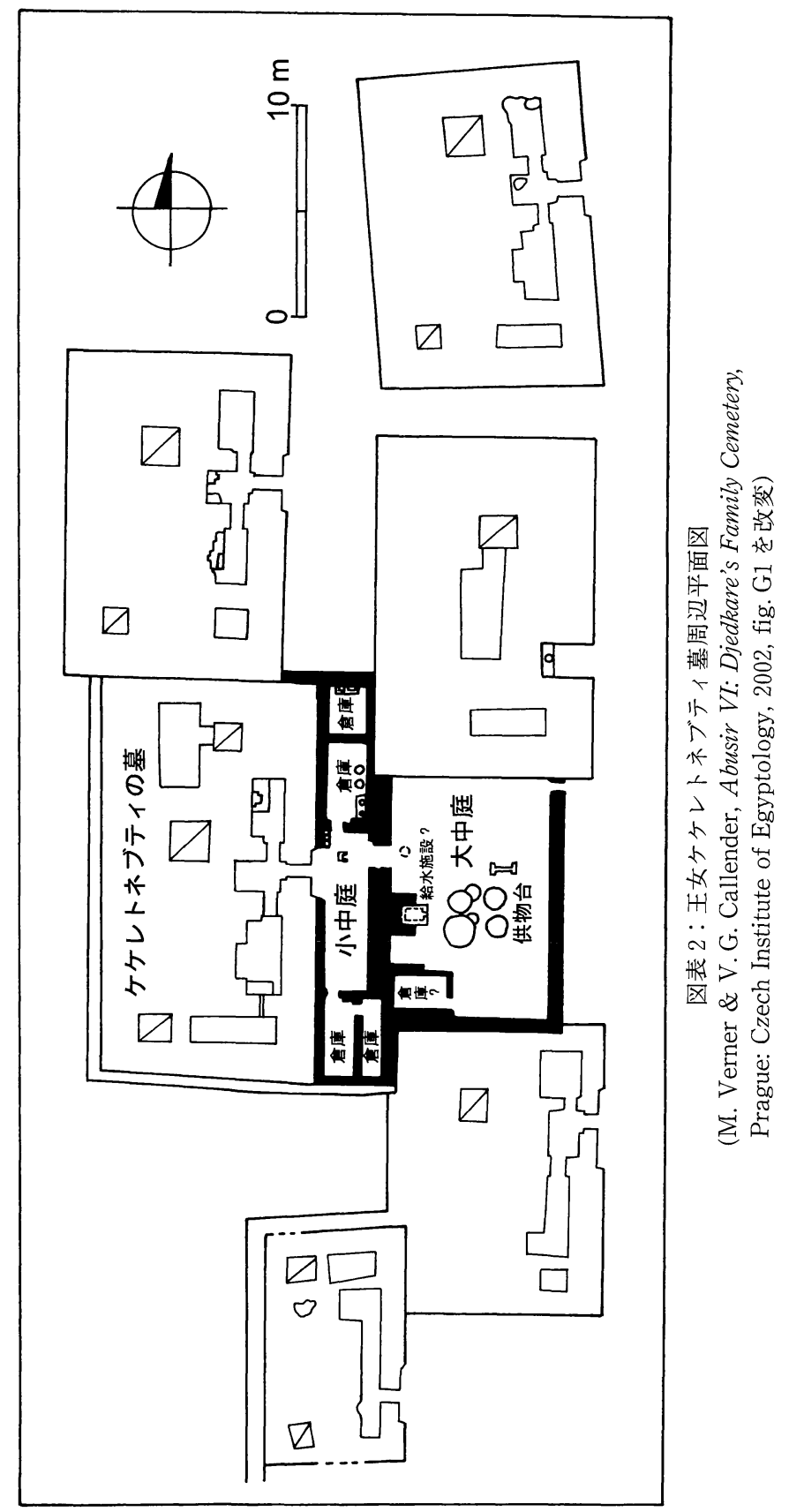




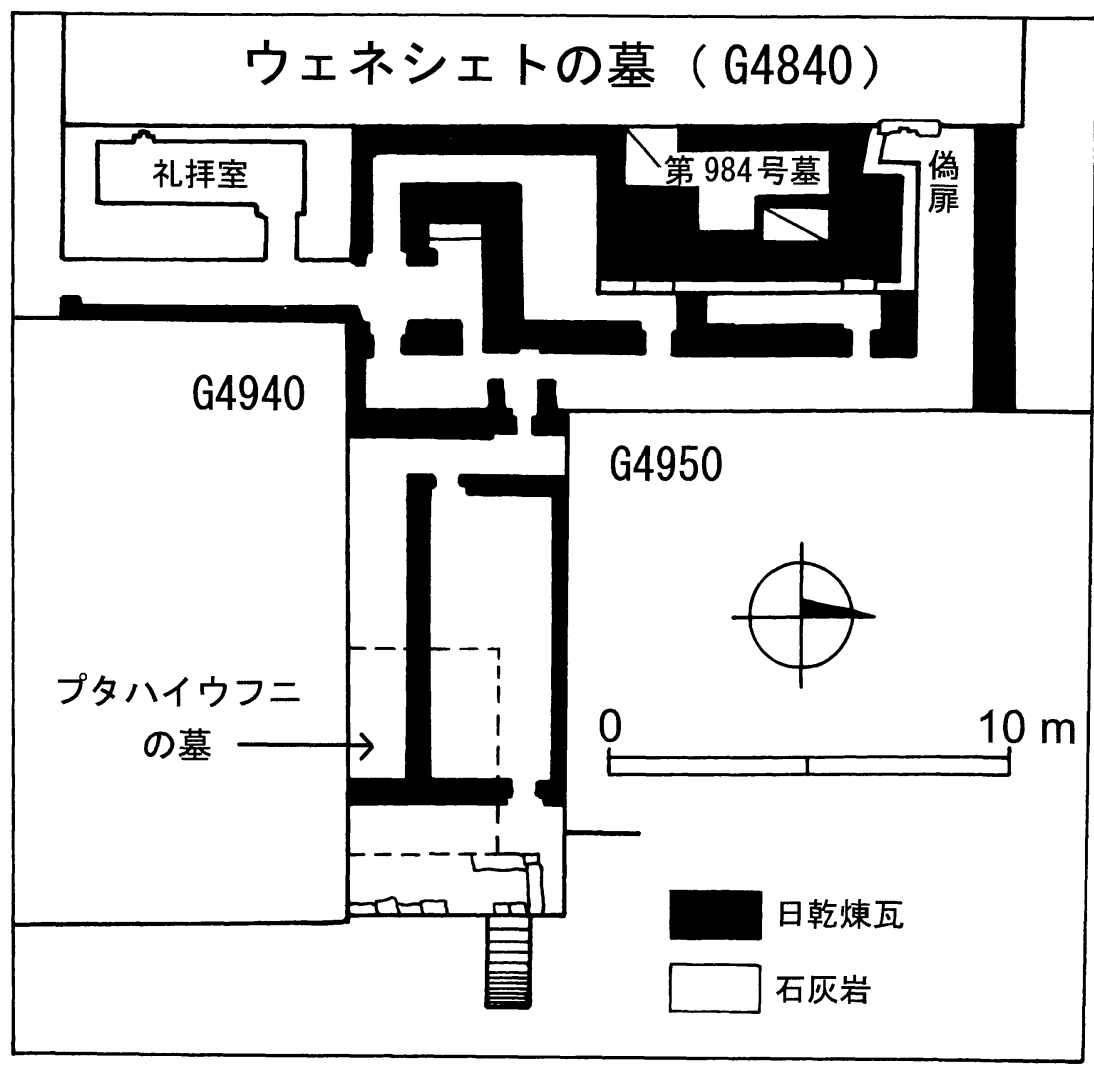

図表 3：王女ウェネシェト祭祀施設復原平面図 (Junker, Giza VII, Abb. 6 を改变) 


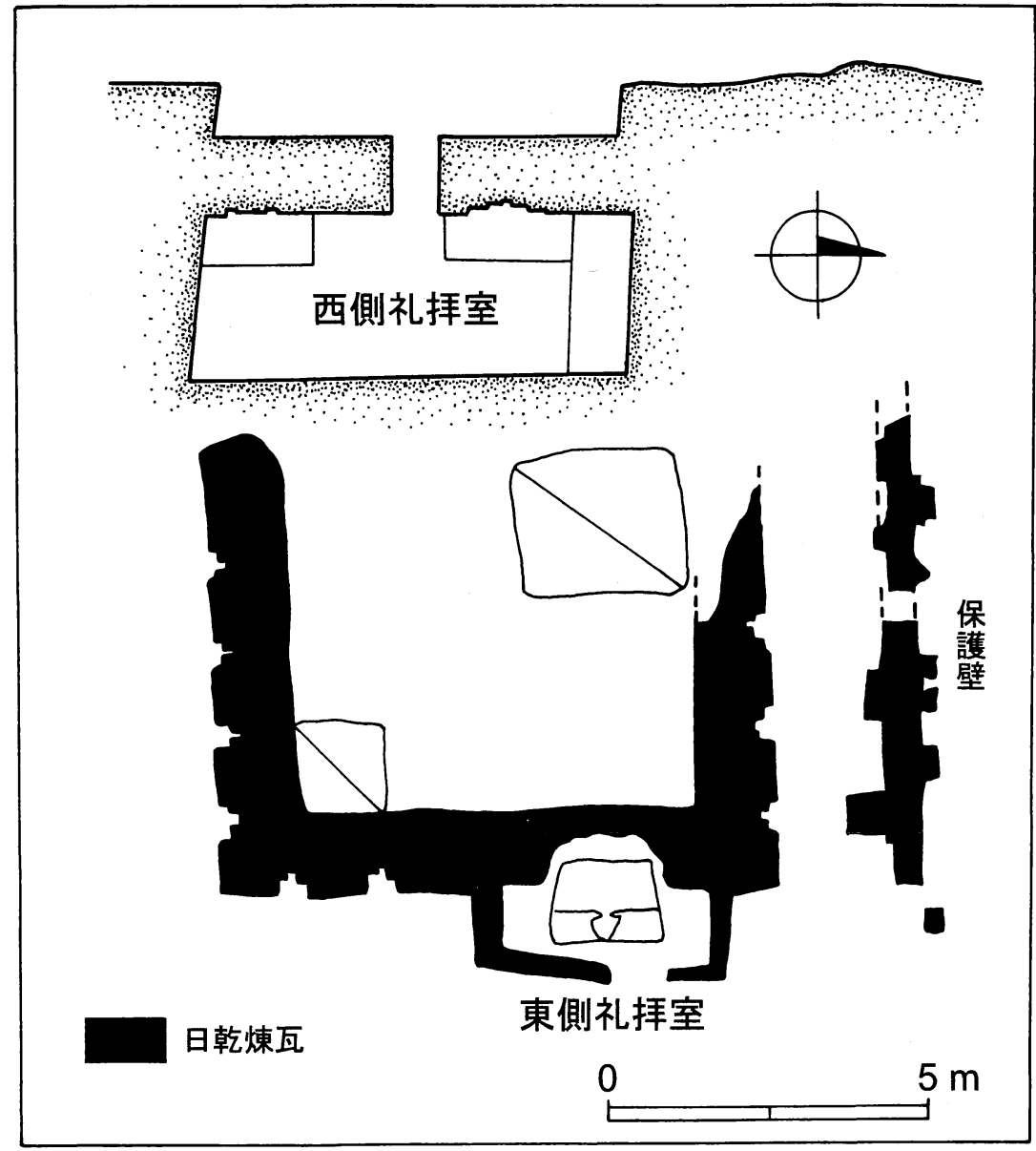

図表 4 : 宰相メルエフネブエフ祭祀施設平面図

(K. Myśliwiec et al., Saqqara I: The Tomb of Merefnebef, Warsaw: Zaś Pan \& Neriton, 2004, Pl. 6 を改変) 


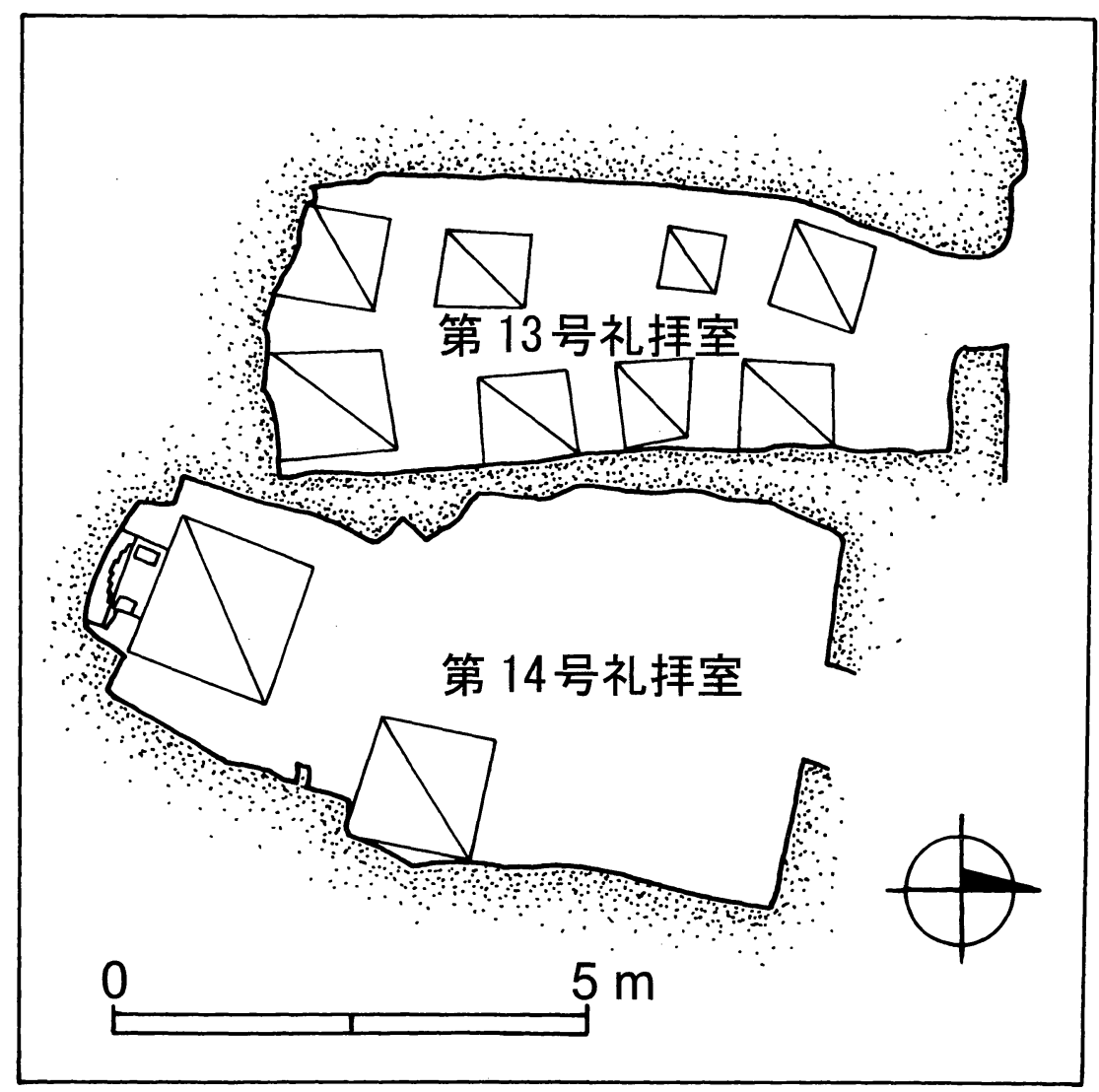

目表 $5:$ 第13号礼帱室」平面図

(K. Myśliwiec, "West Saqqara in 2002," Polish Archaeology in the Mediterraniean 14, fig. 11 を改変) 


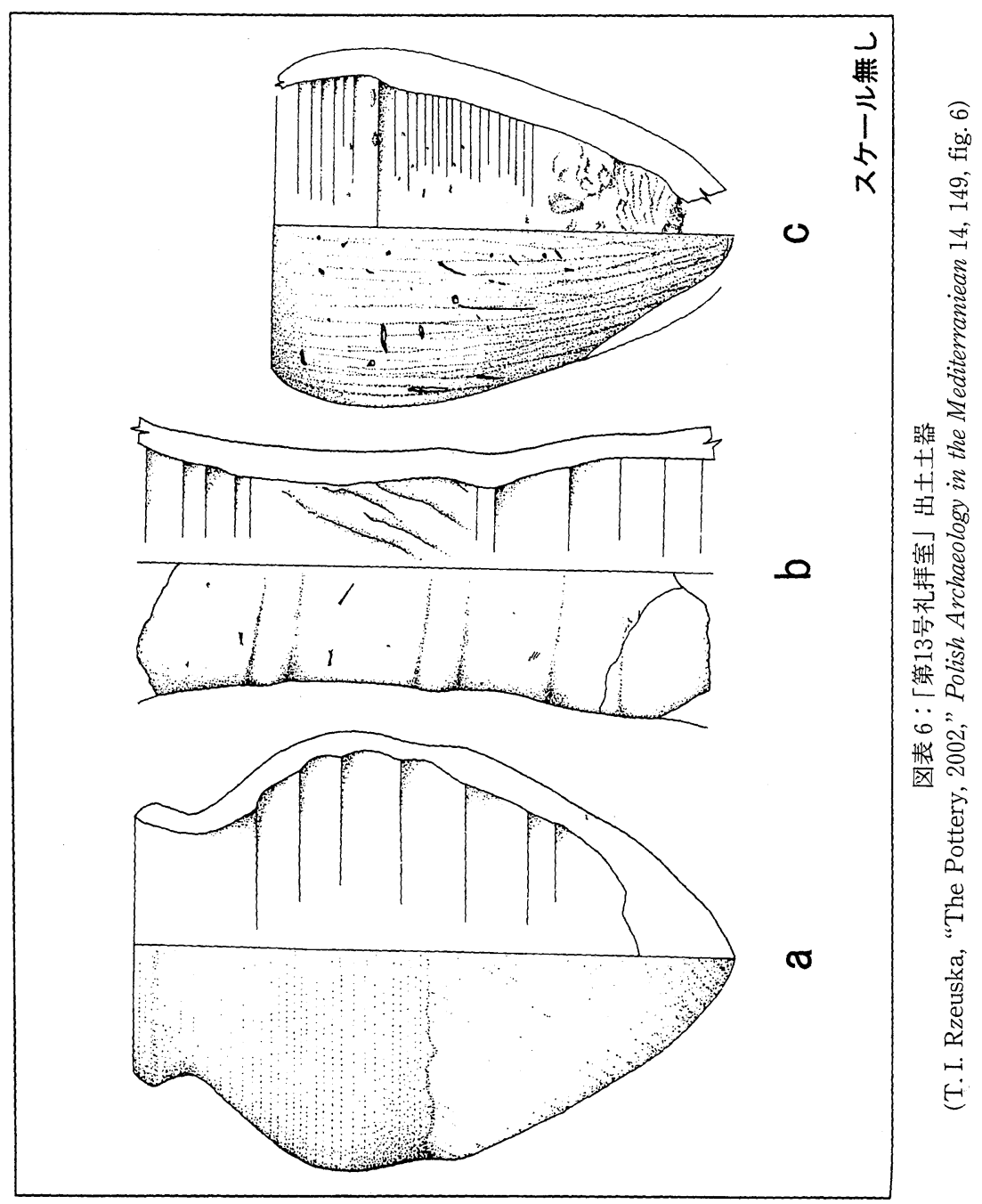




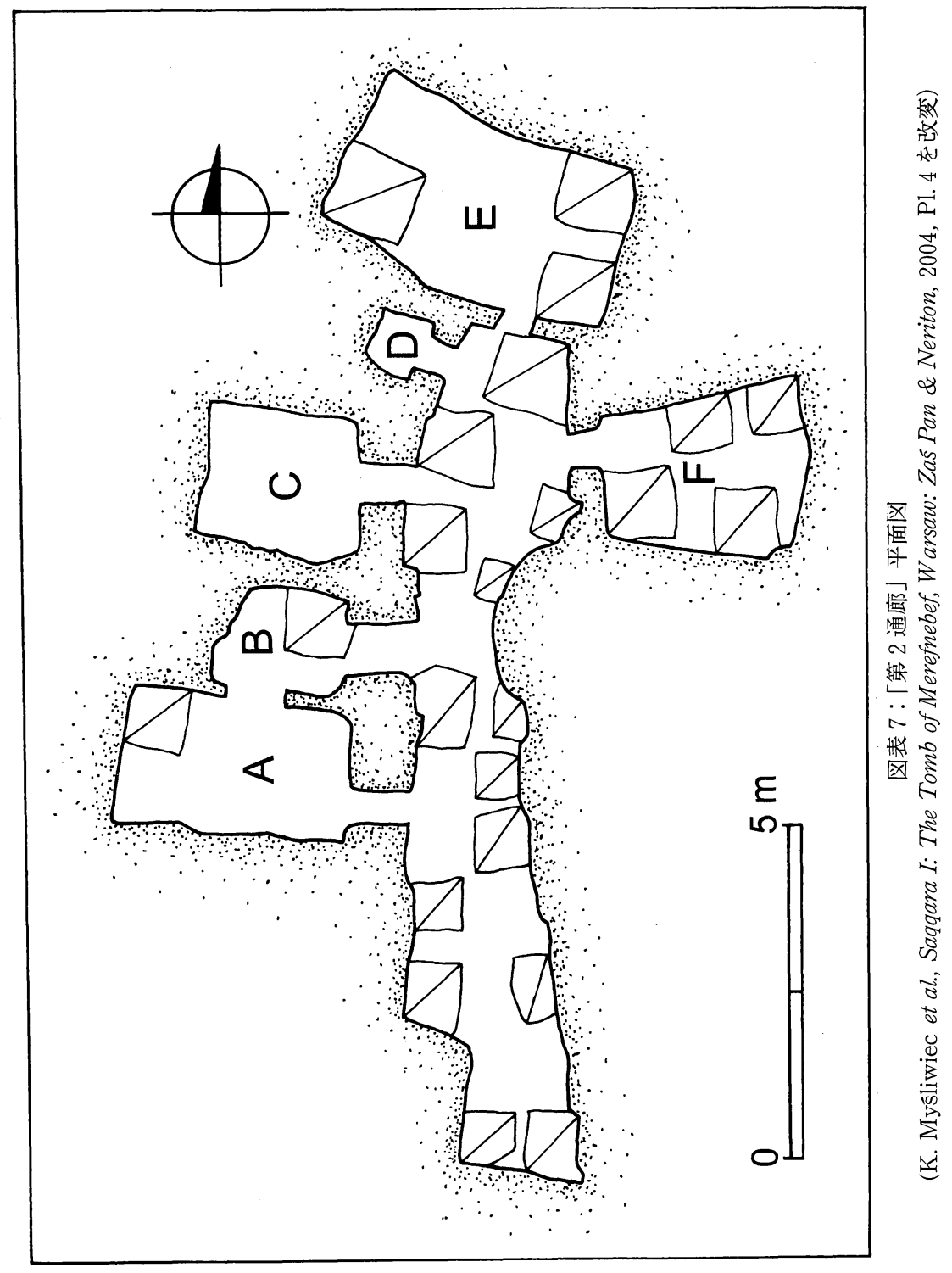




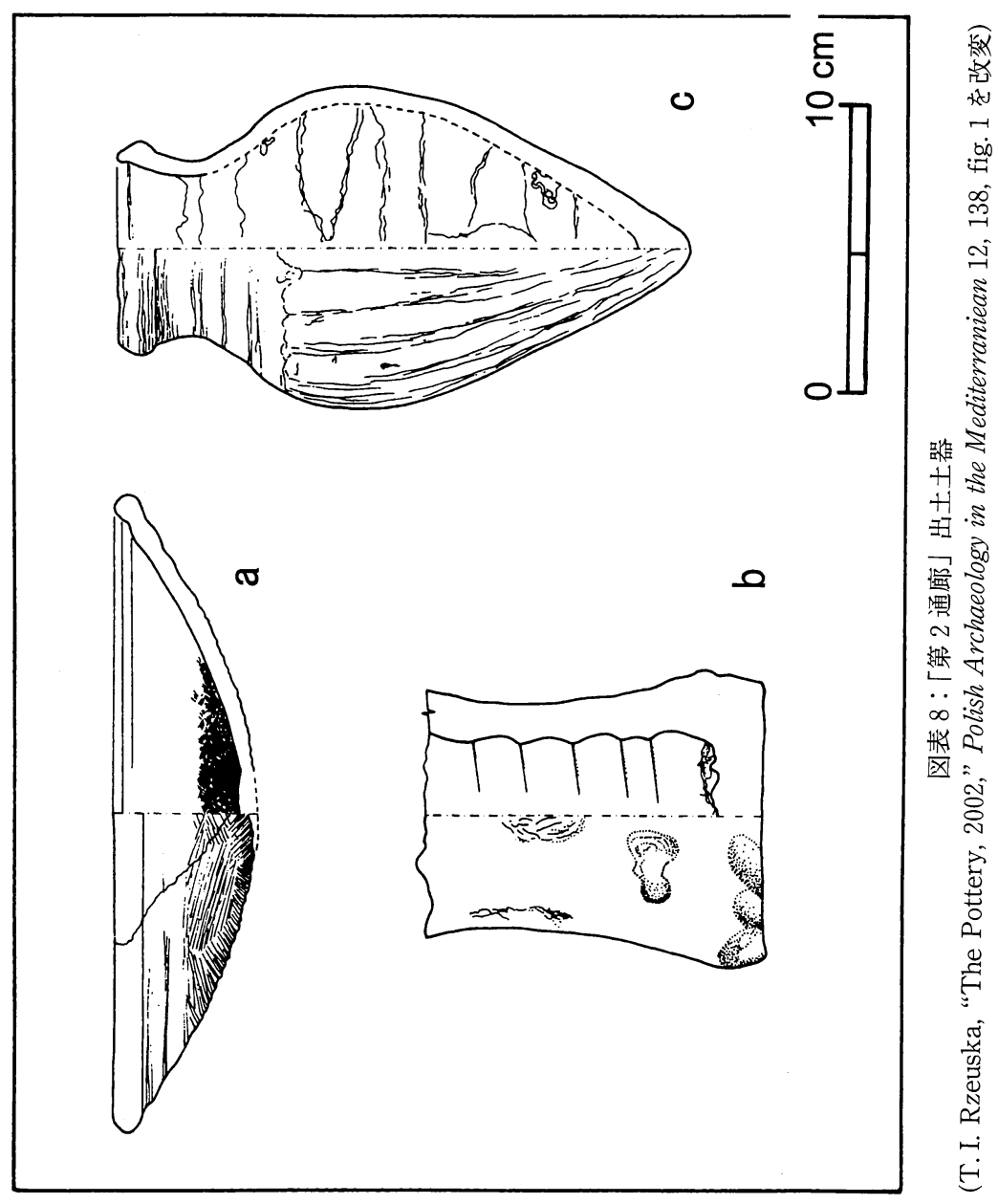

